\title{
Effect of Compensation, Quality of Work Life on Performance
}

\author{
Irsan Komar $^{1}$, Ida Aju Brahmasari ${ }^{1}$, Riyadi Nugroho ${ }^{1}$
}

Faculty of Economics and Business, 17 Agustus 1945 University Surabaya, Indonesia

Received: February 2, 2021

Revised: March 13, 2021

Accepted: March 27, 2021

\begin{abstract}
This study aims to determine the effect of compensation, quality of work life on employee performance at the Directorate General of Customs and Excise, East Java Regional Office I. The study population was 1323 employees. employees, the number of samples is 200 respondents. The technique of collecting data through a questionnaire. Model testing with structural equation modeling (SEM) analysis. The test results show that the model (fit) can be seen from the values of GFI, AGFI, TLI, CFI, RMSEA and CMIN / DF respectively 0.902, $0.907,0.964,0.968,0.026$ and 1.127 which indicate the model fit criteria. The results showed that: 1) Compensation has a significant effect on Quality of Work Life, 2) Compensation has a significant effect on Performance, 3) Quality of Work Life has a significant effect on Performance, 4) Compensation has no significant effect on Performance through Quality of Work Life for Office employees Region of the Directorate General of Customs and Excise, East Java I
\end{abstract}

Keywords: Compensation, Quality of Work Life, Performances

\section{Introduction}

The main goal for an organization is performance. Performance can affect the ongoing activities of a company organization, the better the performance shown by employees will greatly help the development of the organization or company.

Compensation is an important factor for employees as individuals because the amount of compensation reflects the size of the value of their work among the employees themselves, their families, and the community. Compensation can be given directly such as salary, other payments based on work performance (Bernardin \& Russel, 2010).

The existence of the corona virus disease (covid 19) entered Indonesia since the beginning of 2020, at the Regional Office of the Directorate General of Customs and Excise, East Java I experienced the threat of failure to achieve the predetermined state revenue target. Regional Offices and Service Offices cannot carry out normal work activities, due to government regulations to stay at home, social distancing and large-scale social restrictions (PSBB). Current conditions encourage all Jatim I Customs employees to adapt and implement Flexible Working Space (FWS), through the implementation of Work From Home (WFH). The implementation of WFH as a new way of working is expected to create an adaptive work culture with integrity in the future. With the hope that the main performance indicator target of the Regional Office of the Directorate General of Customs and Excise, East Java I can be achieved, in accordance with the work agreement document or work contract.

The compensation received by employees of the Directorate General of Customs and Excise is currently based on financial rewards, namely remuneration, performance allowances and premiums. The value of financial compensation received by permanent employees is lower than the rate of increase in the rate of inflation, for example the increase in prices for basic necessities, fuel oil and transportation costs. 
In addition to the compensation factor, fair promotion opportunities, adequate income, pleasant colleagues and superiors, so that employees feel more comfortable at work are quality of work life factors that can improve employee performance (Robbins \& Judge, 2013). Judging by the quality of work life factors, in completing their duties, employees still do not feel the opportunity to be involved in making organizational policies, comfort communicating with leaders. In addition, the work environment is still not good and comfortable, due to the limited workspace and office space available and not in accordance with the number of available employees, resulting in the placement of work facilities and equipment that are not organized and properly organized.

\section{The proposed hypothetical model}

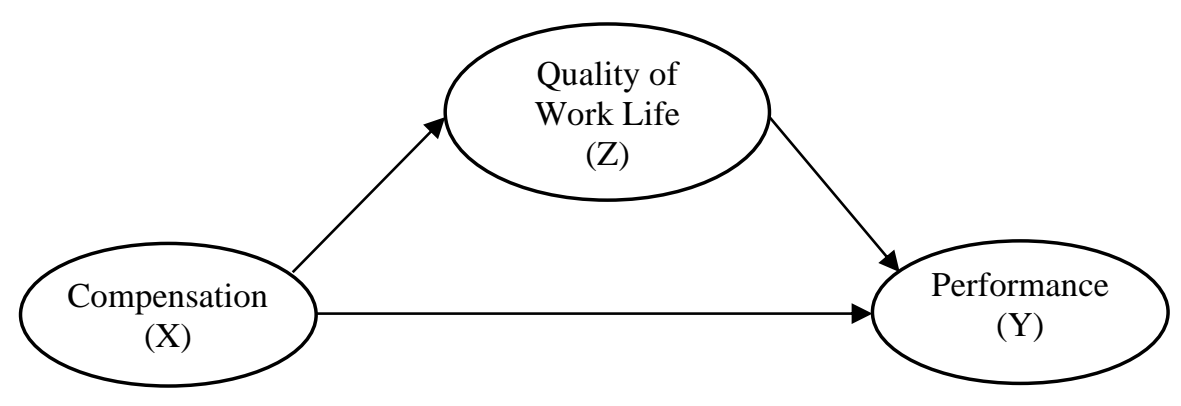

Figure 1. The proposed hypothetical model

Picture. Fig. 1 describes the proposed hypothetical causal model. Each model component is selected based on a literature review. Previous studies revealed that performance is affected by compensation (Supriyanto, 2005; Jahid, 2015; Zulkarnaen \& Herlina, 2018; Alianto \& Anindita, 2018), quality of work life is influenced by compensation and performance is influenced by quality of work life (Nurbiyati, 2014).

\section{Review of construct theory}

\section{Compensation}

Compensation is a company reward for sacrificing their time, energy and thoughts that have been given to the company. Compensation is defined as any form of reward given to employees as remuneration for their contribution to the organization (Torang, 2013). Compensation is calculated based on job evaluation based on worth and equity (Tohardi, 2012; Notoatmodjo, 2009). If compensation is felt to be inappropriate and unfair to employees, it can be a source of social jealousy.

Compensation is the total remuneration received by employees as a result of performing work in the organization in the form of direct and indirect compensation. Direct compensation in the form of salaries, wages, bonuses, incentives, health benefits, holiday allowances, food allowances, leave money and others (Hasibuan, 2008; Gitosudarmo, 2007; Simamora, 2004). Indirect compensation is in the form of an award program for employee performance, which brings benefits to the organization or company (Nawawi, 2018).

\section{Quality of Work Life}

For someone, Quality of Work Life is a pleasant or unpleasant situation in the work environment. Its main objective is the development of an excellent work environment for employees as well as for production. The main focus of Quality Of Work Life is the work environment and all work in it must be suitable for people and technology (Davis \& Newstrom, 1985) 
Quality of Work Life as a management system approach to coordinating and connecting the potential of human resources in the organization, as an effort by the leadership to meet the needs of members and organizations simultaneously and continuously (Sumarsono, 2009).

Quality Of Work Life as every activity (improvement) that occurs at every level in an organization to increase greater organizational effectiveness through increasing human dignity and growth (Flippo, 2005).

\section{Performance}

Performance is a record of the results obtained from certain job functions or certain activities during a certain period of time. Performance as the results (outcomes) of a job and employee contributions to the organization. Employee performance is a function of the interaction between motivation and opportunity abilities (Robbins \& Judge, 2013). Performance as the result or output of a process. Furthermore, it is formulated that performance is formed by two factors, namely ability and motivation. Motivation is related to the willingness or desire to do work (Rivai \& Basri 2005). A person's performance is a combination of abilities, efforts and opportunities that can be had from the results of his work (Amins, 2009). Performance is an activity to improve the quality or quality of work of an employee who will later determine the assessment of a position for a personnel (Nawawi, 2018). Based on this definition, it is very clear that performance shows the quality or quality of employee work and is used as the basis for granting positions. Employees who have high performance will be given a higher position (promotion) and vice versa, employees with low performance are likely to be demoted or transferred to another department (transfer).

\section{Study locations and samples}

The data for this study were collected using a self-administered questionnaire method at the Regional Office of the Directorate General of Customs and Excise, East Java I, Surabaya. A total of 200 questionnaires were distributed to employees as respondents.

\section{Questionnaire design and research variables}

This research was conducted using compensation variables, quality of work life variables and performance variables. The compensation variable construct consists of 8 items, the quality of work life variable consists of 8 items, and the performance variable consists of 8 items. A fivepoint Likert-type scale was used as the response format, with the values assigned as $1=$ Strongly disagree, 2 = Disagree, 3 = Neutral Category, $4=$ Agree Category, and $5=$ Strongly Agree Category.

\section{Analysis of data and results}

The properties of the three research constructs (one exogenous - (1) compensation; and two endogenous - (1) quality of work life and (2) performance) in the proposed model were tested by Amos' structural equation modeling (SEM) procedure (Hair et al. 2010; Ferdinand, 2016).

\section{Structural Equation Modeling (SEM) Test}

The SEM test was carried out to determine whether the 200 questionnaire results were distributed to the sample data. Model test obtained Chi-square $=386.167$, Degrees of freedom $=249$, Probability level $=0.000$. Because the value of the Probability level $=0.000$, below the value of 0.05 indicates that the distribution of 200 questionnaire results data is still not suitable (fit) with the sample data. In order for the questionnaire result data to fit (fit) with the sample data, modification of the number of questionnaire results data distribution was carried out by 
reducing the number of questionnaire results data distribution. The reduction was carried out based on the Mahalanobis d-squared table.

After subtracting 10 outlier category data, the result is a distribution model test of 190 questionnaire results obtained Chi-square $=280,641$, Degrees of freedom $=249$, Probability level $=0.083$. Because the value of Probability level $=0.083$, above the value of 0.050 indicates that the distribution of 190 questionnaire results data is in accordance (fit) with the sample data.

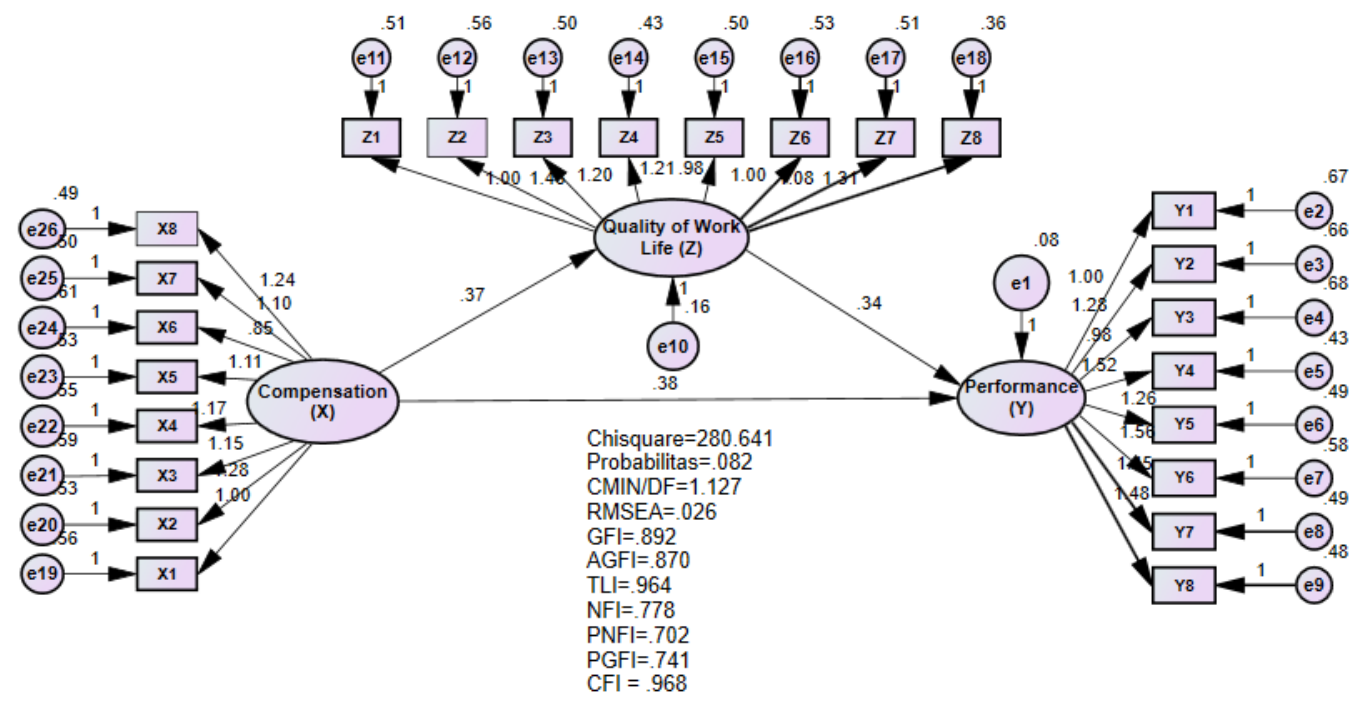

Figure 1. Structural Equation Modeling (SEM)

The results of the calculation of the value of goodness of fit generated by SEM are as follows:

Table 1. Goodness of Fit SEM Value

\begin{tabular}{|c|c|c|c|}
\hline Criteria & $\begin{array}{c}\text { Model Test } \\
\text { Results }\end{array}$ & $\begin{array}{c}\text { Critical } \\
\text { Value }\end{array}$ & Description \\
\hline Probability & 0,083 & $\geq 0,05$ & Fit \\
\hline Cmin/DF & 1,127 & $\leq 2,00$ & Fit \\
\hline RMSEA & 0,026 & $\leq 0,08$ & Fit \\
\hline GFI & 0,902 & $\geq 0,90$ & Fit \\
\hline AGFI & 0,907 & $\geq 0,90$ & Fit \\
\hline TLI & 0,964 & $\geq 0,95$ & Fit \\
\hline CFI & 0.968 & $\geq 0,95$ & Fit \\
\hline
\end{tabular}

Table 1 shows that most of the model suitability criteria (goodness of fit) have provided a fit index, namely Probability $\mathrm{Prob}^{2}$ square, Cmin / DF, Root Mean Square Error Of Approximation (RMSEA), Goodness-of-fit-index (GFI), Adjusted Goodness Of Fit Index (AGFI), Tucker Lewis Index (TLI), and Comparative Fit Index (CFI).

\section{Normality Test}

The results of the data normality test of the questionnaire results are as follows:

Table 2. Normality Test Results

\begin{tabular}{|l|r|r|r|r|r|r|}
\hline Variable & $\min$ & $\max$ & skew & c.r. & kurtosis & c.r. \\
\hline $\mathrm{x} 46$ & 2.000 & 5.000 & -.314 & -1.765 & -.400 & -1.126 \\
\hline $\mathrm{x} 45$ & 2.000 & 5.000 & -.138 & -.774 & -.638 & -1.794 \\
\hline
\end{tabular}

Copyright @ (2021, Journal of Asian Multicultural Research for Economy and Management Study, Under the license CC BY-SA 4.0 


\begin{tabular}{|l|r|r|r|r|r|r|}
\hline Variable & $\min$ & $\max$ & skew & c.r. & kurtosis & c.r. \\
\hline x44 & 2.000 & 5.000 & -.191 & -1.075 & -.552 & -1.554 \\
\hline x54 & 2.000 & 5.000 & -.203 & -1.144 & -.753 & -2.119 \\
\hline x53 & 2.000 & 5.000 & -.149 & -.837 & -.841 & -2.365 \\
\hline x52 & 2.000 & 5.000 & -.120 & -.676 & -1.036 & -2.516 \\
\hline x51 & 2.000 & 5.000 & -.029 & -.162 & -.746 & -2.100 \\
\hline x50 & 2.000 & 5.000 & -.054 & -.303 & -.731 & -2.058 \\
\hline x49 & 2.000 & 5.000 & -.151 & -.849 & -.874 & -2.459 \\
\hline x48 & 2.000 & 5.000 & -.116 & -.655 & -.925 & -2.503 \\
\hline x47 & 2.000 & 5.000 & -.189 & -1.062 & -.807 & -2.272 \\
\hline x28 & 2.000 & 5.000 & -.345 & -1.939 & -.613 & -1.725 \\
\hline x27 & 2.000 & 5.000 & -.072 & -.402 & -.691 & -1.945 \\
\hline x26 & 2.000 & 5.000 & -.195 & -1.096 & -.626 & -1.762 \\
\hline x25 & 2.000 & 5.000 & -.440 & -2.477 & -.623 & -1.752 \\
\hline x24 & 2.000 & 5.000 & -.314 & -1.765 & -.695 & -1.956 \\
\hline x23 & 2.000 & 5.000 & -.304 & -1.709 & -.785 & -2.209 \\
\hline x22 & 2.000 & 5.000 & -.065 & -.365 & -.925 & -2.503 \\
\hline x21 & 2.000 & 5.000 & -.068 & -.385 & -.737 & -2.072 \\
\hline x43 & 2.000 & 5.000 & -.335 & -1.885 & -.434 & -1.222 \\
\hline x42 & 2.000 & 5.000 & -.145 & -.816 & -.611 & -1.719 \\
\hline x41 & 2.000 & 5.000 & -.191 & -1.073 & -.708 & -1.991 \\
\hline x40 & 2.000 & 5.000 & -.104 & -.582 & -1.055 & -2.567 \\
\hline x39 & 2.000 & 5.000 & .093 & .521 & -.606 & -1.705 \\
\hline Multivariate & & & & & 4.701 & .917 \\
\hline
\end{tabular}

Table 2 shows the results of the multivariate normality test which shows the cr multivariate of 0.917 which is in the range -2.58 to +2.58 , and the variable values are in the range -2.58 to +2.58 , so it can be concluded that multivariate questionnaire results data are normally distributed and can be used for further analysis.

\section{Confirmatory Factor Analysis (CFA)}

CFA serves to identify the validity and reliability of the indicators which are the constructs of the research variables.

Validity is used to determine the respondent's interpretation of each statement item contained in the research instrument, whether the interpretation of each respondent is the same or completely different. If the respondent's interpretation is the same, the research instrument can be said to be valid, but if it is not the same then the instrument can be said to be invalid, so the statement items need to be changed. Validity is measured based on the loading factor value. If the loading factor value is greater than or equal to $0.5(\geq 0.5)$ then the indicator in question is valid and means that the indicator is significant in measuring a construct.

Reliability is done to know the respondent's interpretation of the statement items contained in the research instrument which is indicated by the consistency of the answers given. The reliability of the indicator can be seen from the $\mathrm{p}$ value of the error variance, it is said to be reliable if the value is less than $0.05(<0.05)$. Meanwhile, composite reliability was used to calculate construct reliability with a cut off value of at least $0.7(>0.7)$. To get the composite reliability value, the formula is used: 
$\mathrm{CR}=\frac{\left(\sum \lambda\right)^{2}}{\left(\sum \lambda\right)^{2}+\sum\left(1-\lambda^{2}\right)}($ Ferdinand, 2016).

The results of the confirmatory factor analysis test on exogenous variables can be seen in the following table:

Table 3. Confirmatory Factor Analysis of Exogenous Variables

\begin{tabular}{|c|c|c|c|c|c|c|}
\hline \multirow{4}{*}{ Variable } & Indicator & $\begin{array}{c}\text { P Value } \\
\text { variance } \\
\text { error }\end{array}$ & $\begin{array}{c}\text { Loading } \\
(\lambda)\end{array}$ & $\lambda^{2}$ & $1-\lambda^{2}$ & $\begin{array}{c}\text { Construct } \\
\text { Reliability } \\
(\mathrm{CR})\end{array}$ \\
\hline \multirow{5}{*}{$\begin{array}{c}\text { Compensation } \\
(\mathrm{X})\end{array}$} & $\mathrm{x} 21$ & 0,000 & 1,000 & 1,000 & 0,000 & \\
\cline { 2 - 6 } & $\mathrm{x} 22$ & 0,000 & 1,339 & 1,793 & $-0,793$ & \\
\cline { 2 - 6 } & $\mathrm{x} 23$ & 0,000 & 1,189 & 1,414 & $-0,414$ & \multirow{1}{*}{1,034} \\
\cline { 2 - 6 } & $\mathrm{x} 24$ & 0,000 & 1,230 & 1,513 & $-0,513$ & \\
\cline { 2 - 6 } & $\mathrm{x} 25$ & 0,000 & 1,166 & 1,360 & $-0,360$ & \\
\cline { 2 - 6 } & $\mathrm{x} 26$ & 0,000 & 0,847 & 0,717 & 0,283 & \\
\cline { 2 - 6 } & $\mathrm{x} 27$ & 0,000 & 1,167 & 1,362 & $-0,362$ & \\
\cline { 2 - 6 } & $\mathrm{x} 28$ & 0,000 & 1,291 & 1,667 & $-0,667$ & \\
\hline & & Total & 9,229 & & $-2,825$ & \\
\hline
\end{tabular}

Table 3 shows that the exogenous variables consisting of compensation have a CFA (confirmatory factor analysis) value of factor loading greater than 0.50 , all construct reliability is greater than 0.70 , and the $p$-value of variance error is less than $0.05(<0.05)$. ), so it can be concluded that these variables are valid and reliable in constructing the model, and can be used for further analysis.

The results of testing construct reliability on endogenous variables can be seen in the following table:

Table 4. Confirmatory Factor Analysis of Endogenous Variables

\begin{tabular}{|c|c|c|c|c|c|c|}
\hline Variable & Indicator & $\begin{array}{c}\text { P Value } \\
\text { variance } \\
\text { error }\end{array}$ & $\begin{array}{l}\text { Loading } \\
(\lambda)\end{array}$ & $\lambda^{2}$ & $1-\lambda^{2}$ & $\begin{array}{l}\text { Construct } \\
\text { Reliability }\end{array}$ \\
\hline \multirow{9}{*}{$\begin{array}{l}\text { Quality of } \\
\text { Work Life } \\
\quad(\mathrm{Z})\end{array}$} & $\mathrm{x} 39$ & 0,000 & 1,000 & 1,000 & 0,000 & \multirow{8}{*}{1,039} \\
\hline & $\mathrm{x} 40$ & 0,000 & 1,488 & 2,214 & $-1,214$ & \\
\hline & $\mathrm{x} 41$ & 0,000 & 1,232 & 1,518 & $-0,518$ & \\
\hline & $x 42$ & 0,000 & 1,243 & 1,545 & $-0,545$ & \\
\hline & $\mathrm{x} 43$ & 0,000 & 0,985 & 0,970 & 0,030 & \\
\hline & $\mathrm{x} 44$ & 0,000 & 1,011 & 1,022 & $-0,022$ & \\
\hline & $\mathrm{x} 45$ & 0,000 & 1,083 & 1,173 & $-0,173$ & \\
\hline & $\mathrm{x} 46$ & 0,000 & 1,359 & 1,847 & $-0,847$ & \\
\hline & & Total & 9,401 & & $-3,289$ & \\
\hline \multirow{6}{*}{$\begin{array}{c}\text { Performance } \\
\text { (Y) }\end{array}$} & $\mathrm{x} 47$ & 0,000 & 1,000 & 1,000 & 0,000 & \multirow{6}{*}{1,064} \\
\hline & $\mathrm{x} 48$ & 0,000 & 1,319 & 1,740 & $-0,740$ & \\
\hline & $\mathrm{x} 49$ & 0,000 & 0,994 & 0,988 & 0,012 & \\
\hline & $\times 50$ & 0,000 & 1,548 & 2,396 & $-1,396$ & \\
\hline & $\mathrm{x} 51$ & 0,000 & 1,324 & 1,753 & $-0,753$ & \\
\hline & $\mathrm{x} 52$ & 0,000 & 1,632 & 2,663 & $-1,663$ & \\
\hline
\end{tabular}

Copyright @ 2021, Journal of Asian Multicultural Research for Economy and Management Study, Under the license CC BY-SA 4.0 


\begin{tabular}{|c|c|c|c|c|c|c|}
\hline \multirow{2}{*}{ Variable } & Indicator & $\begin{array}{c}\text { P Value } \\
\text { variance } \\
\text { error }\end{array}$ & $\begin{array}{c}\text { Loading } \\
(\lambda)\end{array}$ & $\lambda^{2}$ & $1-\lambda^{2}$ & $\begin{array}{c}\text { Construct } \\
\text { Reliability }\end{array}$ \\
\hline & $\mathrm{x} 53$ & 0,000 & 1,464 & 2,143 & $-1,143$ & \multirow{2}{*}{} \\
\cline { 2 - 6 } & $\mathrm{x} 54$ & 0,000 & 1,518 & 2,304 & $-1,304$ & \\
\hline & & Total & 10,799 & & $-6,988$ & \\
\hline
\end{tabular}

Table 4 shows that the endogenous variables consisting of Quality of Work Life and Performance have a CFA (confirmatory factor analysis) value of factor loading greater than 0.50 , all of the construct reliability is greater than 0.70 , and the $p$-value of the variance error is smaller. of $0.05(<0.05)$, so it can be concluded that these variables are valid and reliable in compiling the model, and can be used for further analysis.

\section{Direct and Indirect Influence}

SEM test results on each variable:

Table 5. SEM Coefficient Value of Influence Between Variables

\begin{tabular}{|l|c|l|l|c|c|}
\hline \multicolumn{2}{|c|}{ Causality Relationship } & $\begin{array}{c}\text { Direct } \\
\text { Effect }\end{array}$ & $\begin{array}{c}\text { Indirect Effect } \\
(\text { Through Z) }\end{array}$ & $\begin{array}{c}\text { Total } \\
\text { Effect }\end{array}$ \\
\hline Compensation $(\mathrm{X})$ & $\rightarrow$ & Quality of Work Life (Z) & 0,369 & - & 0,369 \\
\hline Compensation $(\mathrm{X})$ & $\rightarrow$ & Performance (Y) & 0,376 & - & 0,376 \\
\hline Quality of Work Life (Z) & $\rightarrow$ & Performance (Y) & 0,336 & - & 0,336 \\
\hline Compensation (X) & $\rightarrow$ & Performance (Y) & 0,369 & 0,336 & 0,124 \\
\hline
\end{tabular}

Based on Table 5, it can be explained as that the coefficient value of the Compensation variable has an effect on the Quality of Work Life of 0.369. The coefficient value of the Compensation variable has an effect on Performance of 0.376. The coefficient value of the Quality of Work Life variable has an effect on Performance of 0.336. Compensation coefficient value affects Performance through Quality of Work Life of 0.369 x $0.336=0.124$

\section{Hypothesis Testing}

After knowing the value of the coefficient of each variable, the next step is to test the hypothesis using the CR value and its probability.

Table 6. Test of Causality Regression Weight

\begin{tabular}{|l|l|l|c|r|r|r|r|}
\hline & & Estimate & S.E. & C.R. & P & Description \\
\hline $\begin{array}{l}\text { Compensation } \\
(\mathrm{X})\end{array}$ & $\rightarrow \begin{array}{l}\text { Quality of Work Life } \\
(\mathrm{Z})\end{array}$ & 0,369 & 0,110 & 3,363 & 0,000 & Significant \\
\hline $\begin{array}{l}\text { Compensation } \\
(\mathrm{X})\end{array}$ & $\rightarrow$ Performance (Y) & 0,376 & 0,110 & 3,419 & 0,000 & Significant \\
\hline $\begin{array}{l}\text { Quality of Work } \\
\text { Life (Z) }\end{array}$ & $\rightarrow$ Performance (Y) & 0,336 & 0,103 & 3,252 & 0,001 & Significant \\
\hline
\end{tabular}

Based on Table 6, it can be explained That the estimation results of the parameter of the Compensation variable on the Quality of Work Life show significant results with a CR value of 3.363, this value is greater than 1.96, and the resulting significance level (p-value) is very small ( $\mathrm{p}<0.05$ ). Thus, the first hypothesis which states that Compensation has a positive and significant effect on Quality of Work Life can be accepted. The results of the study reinforce

Copyright @ 0 2021, Journal of Asian Multicultural Research for Economy and Management Study, Under the license CC BY-SA 4.0 
the findings of Gillet et al. (2013). The estimation results of the parameter of the Compensation to Performance variable show significant results with a CR value of 3,419 , this value is greater than 1.96, and the resulting level of significance ( $p$-value) is very small ( $p<0.05)$. Thus, the second hypothesis which states that compensation has a positive and significant effect on performance can be accepted. The results of the study reinforce the findings of Iskandar et al. (2019), Firmandari (2014). The estimation result of the variable parameter Quality of Work Life on Performance shows a significant result with a CR value of 3.252, this value is greater than 1.96, and the resulting significance level ( $\mathrm{p}$-value) is $0.002(\mathrm{p}<0.05)$. These results support the third hypothesis which states that the Quality of Work Life has a positive and significant effect on performance, which is acceptable. The results of the study reinforce the findings of Nurbiyati (2014). Compensation coefficient value affects Performance through Quality of Work Life of $0.369 \times 0.336=0.124<0.376$. Thus, the fourth hypothesis which states that Compensation has a positive and significant effect on Performance through Quality of Work Life, cannot be accepted

\section{Conclusion}

Compensation has a significant effect on the Quality of Work Life of employees of the Regional Office of the Directorate General of Customs and Excise, East Java I, this shows that compensation is able to improve the quality of work life of employees of the Regional Office of the Directorate General of Customs and Excise, East Java I. Compensation has a significant effect on the performance of the employees of the Regional Office of the Directorate General of Customs and Excise, East Java I, this shows that compensation is able to increase the performance of the employees of the Regional Office of the Directorate General of Customs and Excise, East Java I. Quality of Work Life has a significant effect on the performance of employees at the Regional Office of the Directorate General of Customs and Excise, East Java I, this shows that the quality of work life is able to increase the performance of employees of the Regional Office of the Directorate General of Customs and Excise, East Java I. Compensation has no significant effect on Performance through the Quality of Work Life of employees at the Regional Office of the Directorate General of Customs and Excise, East Java I, this shows that Compensation has not been able to increase Performance through the Quality of Work Life of employees of the Regional Office of the Directorate General of Customs and Excise, East Java I.

\section{References}

Achmad, S. R. (2016). Sumber Daya Manusia Berkualitas. Jakarta: Gramedia Pustaka Utama.

Alianto, A., \& Anindita, R. (2017). The Effect of Compensation and Work Life Balance on Work Satisfaction Mediated By Work Stress. International Journal of Business and Management Invention, 7(5), 79-87.

Amins, A. (2009). Manajemen kinerja pemerintah daerah. LaksBang Pressindo. Available from:

https://books.google.co.id/books/about/Manajemen_kinerja_pemerintah_daerah.htm 1 id=L1mykgEACAAJ\&redir_esc=y

Bernardin, H. J., \& Russell, J. E. (2006). Human resource management (p. 736). Tata McGraw-Hill.

Davis, K., \& Newstrom, J. W. (1985). Perilaku dalam Organisasi (Alih Bahasa: Agus Dharma). Jakarta: Erlangga. 
Ferdinand, A. (2006). Metode Penelitian Manajemen: pedoman penelitian untuk skripsi. Thesis \& Disertai Ilmu Manajemen. Semarang: Universitas Diponegoro.

Firmandari, N. (2014). Pengaruh Kompensasi Terhadap Kinerja Karyawan Dengan Motivasi Kerja Sebagai Variabel Moderasi (Studi Pada Bank Syariah Mandiri Kantor Cabang Yogyakarta). Ekbisi, 9(1).

Flippo, E. B. (2005). Manajemen Personalia. Jilid 2. Edisi ke-6. Terjemahan. Erlangga. Jakarta.

Gillet, N., Fouquereau, E., Bonnaud-Antignac, A., Mokounkolo, R., \& Colombat, P. (2013). The mediating role of organizational justice in the relationship between transformational leadership and nurses' quality of work life: A cross-sectional questionnaire survey. International journal of nursing studies, 50(10), 1359-1367.

Gitosudarmo, I. (2007). Manajemen Operasi Edisi Tiga: BPFE Yogyakarta.

Hasibuan, M. S. (2008). Manajemen Sumber Daya Manusia: Jakarta, Indonesia: PT. Bumi Aksara.

Iskandar, K. F., Tumbuan, W. J., \& Sendow, G. M. (2019). Analisis Keterlibatan Kerja, Kualitas Kehidupan Kerja, Dan Insentif Terhadap Kinerja Karyawan Di Pt. Air Manado. Jurnal EMBA: Jurnal Riset Ekonomi, Manajemen, Bisnis dan Akuntansi, 7(3).

Jahid, G. M. (2015). Pengaruh Kompensasi Tidak Langsung terhadap Kinerja Karyawan Direktorat SDM dan Umum di PT. Pos Indonesia (Persero) Kantor Pusat Bandung”. Gaffar Mohammad Jahid (1002099) (Doctoral dissertation, Universitas Pendidikan Indonesia).

Nawawi, H. H. (2018). Manajemen Sumber Daya Manusia untuk bisnis yang kompetitif. Available From: https://ugmpress.ugm.ac.id/id/product/ekonomi-bisnis/manajemensumberdaya-manusia-untuk-bisnis-yang-kompetitif

Notoatmodjo, S. (2009). Pengembangan Manajemen Sumber Daya Manusia. Penerbit Rineka Cipta, Jakarta.

Nurbiyati, T. (2014). Pengaruh quality of work life (qwl) terhadap kinerja pegawai dengan disiplin dan kepuasan kerja sebagai variabel intervening. Jurnal Siasat Bisnis, 18(2), 246-256.

Rivai, V., \& Basri, A. F. M. (2005). Performance Appraisal: Sistem yang tepat untuk menilai kinerja karyawan dan meningkatkan daya saing perusahaan. PT RajaGrafindo Persada.

Robbins, S. P., \& Judge, T. A. (2013). Organizational behavior (Vol. 4). New Jersey: Pearson Education.

Simamora, H. (2004). Manajemen sumber daya manusia. Yogyakarta: stie ykpn, 200.

Sumarsono, S. (2009). Ekonomi Sumber Daya Manusia Teori dan Kebijakan Publik. Jogyakarta: Graha Ilmu.

Supriyanto. (2005). Pengaruh Lingkungan Kerja, Beban Kerja Dan Kompensasi Terhadap Kepuasan Kerja, Komitmen Organisasi Dan Kinerja Petugas Air Traffic Control Pada PT Angkasa Pura I. Available https://opac.perpusnas.go.id/DetailOpac.aspx?id=1227414 
Tohardi, A. (2002). Pemahaman praktis manajemen sumber daya manusia. Universitas Tanjung Pura, Mandar Maju, Bandung.

Torang, S. (2013). Organisasi \& manajemen; perilaku, struktur, budaya \& perubahan organisasi.

http://repo.unikadelasalle.ac.id/index.php?p=show_detail\&id=6238\&keywords $=$

Zulkarnaen, W., \& Herlina, R. (2018). Pengaruh Kompensasi Langsung dan Kompensasi Tidak Langsung terhadap Kinerja Karyawan Bagian Staff Operasional PT Pranata Jaya Abadi Banjaran. Jurnal Ilmiah MEA (Manajemen, Ekonomi, \& Akuntansi), 2(2), 90114. 